\title{
Francesca Scotti, Il deposito nel diritto romano. Testi con traduzione italiana e commento, Torino 2008, XXVIII+244 strony.
}

Nieodzownym elementem studiowania rzymskiego prawa prywatnego jest sięganie do zachowanych źródeł prawa, w szczególności do kodyfikacji Justyniana. Pozwala to nie tylko na poznanie spostrzeżeń jurystów traktujących o poszczególnych instytucjach prawa prywatnego, ale przede wszystkim na obserwację ich nierzadko rozbieżnych konstatacji na ten temat. Stąd też różne wybory źródeł prawa rzymskiego, służące do celów dydaktycznych, stanowią istotny składnik dydaktyki tego przedmiotu, a ich autorzy ${ }^{1}$ nie zawężają się jedynie do prezentacji konkretnej instytucji prawnej, lecz koncentrują swoją uwagę na takiej antologii fragmentów źródłowych, aby student mógł poznać szerokie spektrum prawa rzymskiego.

Recenzowana książka wyróżnia się zdecydowanie na tym tle, ponieważ autorka skupiła się na przedstawieniu źródeł prawa dotyczących wyłącznie depozytu (depositum), dokonując ich przekładu na język włoski i opatrując stosownym komentarzem. W strukturze pracy można wyodrębnić dwa elementy: początkowe części to prezentacja instytucji depozytu w źródłach prawa (Parte prima: Istituzioni di Giustinano e Instituzioni di Gaio, s. 1-13; Parte seconda: Il deposito nel trentesimo libro del Commentario di Ulpiano all'editto, s. 15-60; Parte terza: Digesto di Giustiniano, libro 16, titolo, 3 Depositi vel contra, s. 61-99; Parte quarta: Testi sul deposito tratti da libri e titoli del Digesto di Giustiniano diversi da D.16.3, s. 101-150; Parte quanta: Collatio, titolo 10 De deposito, s. 151-165; Parte sesta: Codice Giustinianeo, libro 4 titolo 34, Depositi, s. 167-181). Drugi element pracy stanowią natomiast merytoryczne rozważania autorki na temat depositum irregularae w prawie rzymskim (Parte settima: Osservazioni sul deposito „irregolare”, s. 183-203). Warto również wskazać na rozbudowaną ilość dodatków, wśród

1 W polskiej romanistyce można wskazać dwa trendy dotyczące przygotowywania fontes iuris do celów dydaktycznych. Początkowe wybory źródeł były przedstawiane tylko w oryginale (język łaciński) - np. R. Taubenschlag, Wybór źródeł do rzymskiego prawa prywatnego (do użytku seminaryjnego), Warszawa 1931. Wynikało to tego, że ówcześni studenci mieli lepsze przygotowanie z języków klasycznych, wyniesione z edukacji w szkole średniej. Drugi, dominujący nurt polega na paralelnej prezentacji tekstu łacińskiego z tłumaczeniem na język polski - np. J. Glemp, Lexiculum prawa rzymskiego. Wybór tekstów łacińskich z tłumaczeniem i polskimi objaśnieniami, Warszawa 1974; W. Osuchowski, Wybór źródeł rzymskiego prawa prywatnego. Tekst z polskim przekładem, Kraków 1982; W. Bojarski, W. Dajczak, A. Sokala, Verba iuris: reguty i kazusy prawa rzymskiego, wyd. 1 Toruń 1995, wyd. 2 Toruń 2007; J. Rominkiewicz, E. Szymoszek, I. Żeber, Prawo rzymskie. Teksty źródłowe do ćwiczeń, wyd. 1 Wrocław 1991, wyd. 2 Wrocław 1994, wyd. 3 Wrocław 1998. Najobszerniejszy wybór (ss. 372) stanowi praca A. M. Wasyl oraz T. Palmirskiego, 'Responsa prudentium' - wybór tekstów źródłowych zawierajacych poglady rzymskiej jurysprudencji, Kraków 2000, choć zawiera tylko teksty w języku polskim. Z drugiej jednak strony dołączenie do tak bogatego wyboru jeszcze łacińskich fragmentów pochodzących z Digesta Iustiniani doprowadziłoby prawdopodobnie do podwojenia objętości tej pomocy dydaktycznej. 
których czytelnik może znaleźć strukturę edictum perpetuum zrekonstruowanego przez Otto Lenela, wyciąg fragmentów autorstwa Ulpiana z Palingenesia Iuris Civilis, wyciąg z Digesta Iustiniani (D.16.3 Depositi vel contra), czy wreszcie wyciąg z Codex Iustinani (C.4.34.4 Depositi) - s. 207-230. Całość dopełnia indeks źródeł, zredagowany w sposób chronologiczny, pozwalający w łatwy sposób odszukać konkretny fragment. Zabrakło tylko bibliografii, która zdecydowanie ułatwiłaby odnalezienie interesującej czytelnika publikacji A tak pozostaje żmudne śledzenie przypisów w celu odszukania całego bibliograficznego zapisu konkretnej pozycji.

Zgodnie z wprowadzeniem, które napisał Giovanni Negri², książka adresowana jest do szerokiego kręgu odbiorców (m.in. doktorantów, absolwentów wyższych uczelni, lektorów itd.), wśród których wyjątkowe miejsce zajmują studenci uczestniczący w zajęciach specjalizacyjnych poświęconych prawu rzymskiemu (s. XI).Wydaje się, że jest to słuszne założenie, bowiem przed przystąpieniem do studiowania pracy F. Scotti, należałoby zapoznać się z podstawowymi instytucjami prawa rzymskiego (co zresztą autorka sugeruje - s. XXI-XXII) w celu poprawnego zrozumienia myśli jurystów. Książka nie aspiruje do przedstawienia nowego spojrzenia na depozyt w prawie rzymskim ani do polemizowania z romanistami, którzy zajmowali się tym zagadnieniem. F. Scotti przytacza jedynie ich rozważania, komentując konkretny fragment źródłowy i stara się skłaniać ku tezom zaproponowanym przez badaczy analizujących instytucję depozytu w ciągu ostatnich 10 lat (s. XII). Jednak z drugiej strony G. Negri dostrzega ważny wkład autorki w dyskusję nad konstrukcją depozytu nieprawidłowego (depositum irregularae) (s. XV). Stąd też praca F. Scotti nie może być postrzegana jako typowy wybór źródeł prawa, przewidziany dla studentów jako dodatkowa pomoc w pogłębianiu nabytej już wiedzy z prawa rzymskiego.

Przechodząc do szczegółowej analizy książki F. Scotti, należy podkreślić, że zaproponowany przez autorkę układ źródeł skłania do stwierdzenia, iż jest to raczej struktura problemowa. Nie jest to z pewnością chronologiczna prezentacja źródeł, skoro po części drugiej (rozważania Ulpiana dotyczące depozytu w komentarzu ad edictum), trzeciej i czwartej (Digesta Iustiniani i stosowne fragmenty poświęcone depositum) autorka wymienia przedjustyniański zbiór prawa - Collatio Legum Mosaicarum et Romanarum, by ponownie w części szóstej powrócić do jednej z części kodyfikacji Justyniana, jaką był Codex. Nie można tego poczytywać w żaden sposób za mankament pracy, zasadnicza bowiem sedes materiae dotycząca depozytu została przedstawiona przez F. Scotti we wcześniejszych częściach pracy, a Collatio i Codex stanowią swoiste uzupełnienie wywodów jurysprudencji klasycznej.

Punktem wyjścia rozważań autorki jest prezentacja źródeł poświęconych prawu procesowemu z Instytucji Gaiusa oraz Justyniana dotyczących m.in. depozytu. Jest to

${ }^{2}$ Profesor zwyczajny w Università Cattolica del Sacro Cuore, sede di Milano. Prof. G. Negri był promotorem pracy magisterskiej autorki, zatytułowanej Commento esegetico del titolo Si quadrupes pauperiem fecisse dicatur nel Digesto giustinianeo; wszystkie informacje zostały zaczerpnięte ze strony internetowej - http://docenti.unicatt.it/web/profilo.do z 24 sierpnia 2009 r. 
szczególnie widoczne przy wskazywaniu fragmentów z czwartego komentarza Gai Institutiones, gdzie autorka przytoczyła te przekazy, które referują pośrednio bądź wprost do kwestii depozytu w aspekcie prawa procesowego (zob. G. IV, 39-40, 45-47, 58-60, 62, s. 4-13). Przedstawienie na samym początku problematyki rzymskiego procesu prywatnego jest zgodne z praktyką wykształconą we włoskiej romanistyce ${ }^{3}$, gdzie zagadnienia procesowe poprzedzają rozważania o poszczególnych instytucjach prawa rzymskiego ${ }^{4}$.

Kolejne karty pracy wprowadzają czytelnika w coraz bardziej szczegółowe informacje dotyczące depozytu. Komentarz Ulpiana do edyktu (zob. s. 15-60) czy też przytoczone księgi 16 oraz fragmenty innych ksiąg Digesta Iustiniani, traktujących o depozycie (zob. s. 61-150), pozwalają kompleksowo analizować instytucję depozytu w prawie rzymskim. Sprzyja temu także obszerny komentarz do przetłumaczonych tekstów łacińskich $^{5}$, który nie tylko sprowadza się do wyjaśnienia kontekstu wypowiedzi jurysty (gdy nie jest on czytelny wprost $\mathrm{z}$ danego fragmentu źródłowego), ale wskazuje inne teksty źródłowe, również przetłumaczone z języka łacińskiego, które pozwalają lepiej zrozumieć rozważania jurysty (np. s. 82, przyp. 398, s. 84 przyp. 402, s. 96 przyp. 479, s. 117 przyp. 569, s. 143 przyp. 710, s. 144 przyp. 713). Autorka odnotowuje interpolacje ${ }^{6}$ w cytowanych tekstach (np. s. 61 przyp. 269, s. 65 przyp. 295, s. 90 przyp. 435), a także przytacza inną możliwość zestawienia komentowanego tekstu (np. s. 27 przyp. 10, s. 77 przyp. 373). Cennym zabiegiem autorki jest zdefiniowanie, z jakiej konkretnie księgi pochodzi fragment źródłowy traktujący o depozycie, a nieumieszczony przez kompilatorów justyniańskich w D. 16.3 (zob. np. s. 34 przyp. 142, w szczególności cała część czwarta pracy). Dzięki temu czytelnik może zorientować się, że rozważania o depozycie kompilatorzy justyniańscy umieszczali również w innych miejscach niż księga 16 tytuł 3, co wynikało z analizy przez jurystę nie tylko samej instytucji depozytu, ale także innych kwestii, które były dominującym elementem układania konkretnej księgi przez komisję kodyfikacyjną. Pozytywnie należy ocenić krótką notę autorki o sposobie cytowania poszczególnych źródeł zawartych np. w Digesta Iustiniani czy też Codex (s. 61 przyp. do tytułu części, s. 167 przyp. do tytułu części). Choć jest to wiedza powszechnie znana, to jednak czasami zaciera się w pamięci i utrudnia zrozumienie poszczególnych cyfr (liczb) przy danym fragmencie źródłowym.

3 Zob. np. B. Biondi, Istituzioni di diritto romano, wyd. 4, Milano 1972, s. 81-102; A. Guarino, Diritto privato romano, wyd. 12, Napoli 2001, s. 157-259. Por. V. Arangio-Ruiz, Istituzioni di diritto romano, wyd. 14, Napoli 2006, s. 107-161.

4 Wśród polskich romanistów także można wskazać zwolenników takiej prezentacji rzymskiego procesu cywilnego: R. Taubenschlag, Rzymskie prawo prywatne, Warszawa 1955, s. 84-106; W. Osuchowski, Zarys rzymskiego prawa prywatnego, wyd. 4, Warszawa 1971, s. 144-216; W. Rozwadowski, Prawo rzymskie. Zarys wykładu wraz z wyborem źródeł, wyd. 2, Poznań 1992, s. 57-84; K. Kolańczyk, Prawo rzymskie, wyd. 5, Warszawa 2000, s. 103-176; A. Dębiński, Rzymskie prawo prywatne. Kompendium, Warszawa 2003, s. 91-135.

5 Warto także odnotować szerokie wykorzystanie literatury przedmiotu, którą autorka przywołuje, komentując poszczególne fragmenty źródeł.

${ }^{6}$ Na temat poglądu autorki na interpolacje - zob. s. XIV recenzowanej książki. 
Część piąta oraz szósta zawiera teksty dotyczące depozytu zamieszczone w Collatio Legum (s. 151-165) oraz Codex (s. 167-181). Można tu zaobserwować skondensowaną, co do zasady (wyjątki - np. s. 153 przyp. 762, s. 162 przyp. 838, s. 177 przyp. 912), formę komentowania tekstów, co wynika z długości i zawartości merytorycznej tych fragmentów źródłowych.

Pewne zdziwienie może budzić niekonsekwentne tytułowanie poszczególnych części pracy w stosunku do tego, co zostało zamieszczone w spisie treści. O ile część trzecia w spisie treści jest zatytułowana Digesto di Giustiniano, libro 16 titolo 3 Depositi vel contra, to już na s. 61 nazwa ta brzmi zupełnie inaczej: D. 16.3. Depositi vel contra. Dell'azione di deposito e dell'azione contraria. To samo dotyczy części czwartej - Testi sul deposito tratti da libri e titoli del Digesto di Giustiniano diversi da D.16.3, a na s. 101 można przeczytać Altre sedes materiae (Digesto), czy też części piątej - Collatio, titolo 10 De deposito, podczas gdy na s. 151 autorka podaje następujący tytuł: Mosaicarum et Romanarum Legum Collatio Titulus X De deposito. Titolo X del deposito. Tożsama niekonsekwencja wypływa w tytulaturze części szóstej, nazwanej w spisie treści Codice Giustinianeo, libro 4 titolo 34, Depositi, a już na s. 167 widnieje następujący tytuł - C.4.34. Depositi. Dell'azione di deposito. Trudno jest wskazać, skąd się wzięły takie rozbieżności w nomenklaturze poszczególnych części w stosunku do spisu treści. Wydaje się, że autorka chciała dokonać paralelnego tłumaczenia także tytułów poszczególnych części, ale takie działanie powinno być ujawnione w obu miejscach - zarówno w spisie treści, jak i właściwym miejscu pracy. Nie jest to może duży mankament publikacji, ale jednak pewne zaskoczenie może wywołać inna nazwa widniejąca na stronicy poświęconej konkretnej części pracy, inna zaś znajdująca się w spisie treści.

Zdumienie mogą budzić edytorskie poprawki tekstów łacińskich dokonanych przez autorkę, polegające na zastąpieniu dwukropka przecinkiem (zob. np. s. 70 przyp. 335, s. 73 przyp. 350, s. 93 przyp. 450, s. 115 przyp. 560, s. 144 przyp.714, s. 148 przyp. 741), usunięciu przecinka z tekstu (zob. np. s. 88 przyp. 426, s. 132 przyp. 659) oraz dokonaniu innych ingerencji interpunkcyjnych w łaciński fragment źródłowy (zob. np. s. 70 przyp. 351, s. 104 przyp. 496, s. 115 przyp. 561, s. 148 przyp. 740 oraz 741). Nie wiadomo do końca, czemu miało służyć to „retuszowanie” źródeł jurydycznych, bo nie wydaje się, aby w znaczący sposób mogło to wpłynąć na deformację myśli jurystów, a pośrednio na kształt przekładu włoskiego.

Ostatnią część pracy (siódmą) stanowią rozważania autorki o depositum irregula$r a e^{7}$. Nie można ich traktować jako wyczerpującego rozstrzygnięcia kwestii depozytu nieprawidłowego, ponieważ F. Scotti koncentruje się tu bardziej na egzegezie tekstów łacińskich, zawierających ślady informacji, pozwalających na interpretowanie tych źródeł

${ }^{7}$ Incydentalnie tej problematyki autorka dotyka w części trzeciej, podczas omawiania fragmentów z D.16.3 (zob. s. 80-90, w szczególności w komentarzu w przypisach). 
w kontekście tej instytucji prawnej. Swoje spostrzeżenia konfrontuje z literaturą przedmiotu, cytując przede wszystkim włoskich romanistów ${ }^{8}$.

Tłumaczenie tekstów prawniczych na języki ojczyste nie jest sprawą łatwą. Każdy, kto zamierza parać się tą trudną sztuką, powinien legitymować się nie tylko obszerną wiedzą z zakresu języka łacińskiego, ale przede wszystkim znajomością siatki pojęciowej stosowanej w romanistyce prawniczej (s. XV). Przekłady tekstów łacińskich na języki ojczyste nie cieszą się dużym zainteresowaniem wśród młodych badaczy ${ }^{9}$. Wydaje się trafne spostrzeżenie G. Negri (s. XVI), że niechęć do tej pracy wynika z konieczności żmudnego i czasochłonnego analizowania tekstów jurydycznych, aby jak najwierniej przetłumaczyć myśl jurysty. Tym samym młodzi romaniści zajmujący się pracochłonnym zajęciem są wysoko oceniani przez G. Negri, który zachęca do podjęcia tego intelektualnego trudu. Czym bowiem byłoby studiowanie prawa rzymskiego bez znajomości źródeł prawa? Czytanie samych podręczników i monografii poświęconych prawu rzym-

${ }^{8}$ Zabrakło tu chociażby symbolicznego odwołania się do pracy J. Sondla, Szczególne rodzaje depozytu w prawie rzymskim, Kraków 1967 (w szczególności s. 34-93), czy też zacytowanie z samego streszczenia tejże pracy w jęz. angielskim (s. 128) stanowiska autora w kwestii depozytu nieprawidłowego. $\mathrm{Z}$ drugiej strony $\mathrm{z}$ uznaniem należy odnotować dostrzeżenie przez autorkę artykułu innego krakowskiego romanisty - T. Palmirskiego, Some Remarks on D. 16.3.15 and 50.17.45 pr., RIDA 51, 2004, s. 196-203 (zob. s. 71 przyp. 341 recenzowanej pracy).

9 Polscy romaniści również podjęli trud przekładu łacińskich źródeł na język polski oraz opatrzenia ich, krótszym niż F. Scotti, komentarzem (wyjątkiem są tu tłumaczenia źródeł dokonane przez B. Sitka - Tabula Heracleensis (Lex Iulia municipalis). Tekst, tłumacznie, komentarz, Olsztyn 2006, ss. 87; Lex Corneliae Gentivae Iuiliae seu Ursonensis i lex Irnitiana. Ustawy municypalne antycznego Rzymu. Tekst, tłumacznie, komentarz, Poznań 2008, ss. 230). Na kartach Zeszytów Prawniczych [UKSW], red. J. Zabłocki, ukazało się kilka tłumaczeń poszczególnych ksiąg Digesta Iustiniani - zob. A. Tarwacka, O początkach prawa $i$ wszystkich urzędów oraz następstwie prawników - II tytu I księgi Digestów. Tekst - tlumaczenie - komentarz, Zeszyty Prawnicze [UKSW] 3.1, 2003, s. 197-242; eadem, O sprawiedliwości i prawie - tytuł 1 księgi 1 Digestów. Tekst - tłumaczenie - komentarz, Zeszyty Prawnicze [UKSW] 3.2, 2003, s. 357-370; eadem, Leges regiae. Tekst - tlumaczenie - komentarz, Zeszyty Prawnicze [UKSW] 4.1, 2004, s. 233-260; eadem, O ustawach, uchwałach senatu i zakorzenionym zwyczaju 3 tytut 1 księgi Digestów. Tekst - tłumaczenie - komentarz, Zeszyty Prawnicze [UKSW] 4.2, 2004, s. 255-271; eadem, O konstytucjach cesarskich - 4 tytuł 1 księgi Digestów. Tekst - tłumaczenie - komentarz, Zeszyty Prawnicze [UKSW] 5.1, 2005, s. 275-278; edaem, O pozycji prawnej ludzi - 5 tytuł 1 księgi Digestów. Tekst - tlumaczenie - komentarz, Zeszyty Prawnicze [UKSW] 8.2, 2008, s. 317-334; E. Loska, Ustawa julijska o przemocy publicznej - 6 tytuł 48 księgi Digestów. Tekst - tłumaczenie - komentarz, Zeszyty Prawnicze [UKSW] 5.2, 2005, s. 229-241; A. Stępkowska, O 'actio rei uxoriae' przekształconej w 'actio ex stipulatu' i o naturze nadanej posagom - 13 tytuł 5 księgi Kodeksu Justyniańskiego. Tekst - tłumaczenie komentarz, Zeszyty Prawnicze [UKSW] 5.2, 2005, s. 243-280; T. Palmirski, O różnych regułach dawnego prawa - 17 tytuł 50 księgi Digestów. Tekst - tlumaczenie - komentarz, Zeszyty Prawnicze [UKSW] 6.2, 2006, s. 221-326; idem, O różnych regułach dawnego prawa - 17 tytuł 50 księgi Digestów. Tekst - tłumaczenie - komentarz, Zeszyty Prawnicze [UKSW] 7.1, 2007,s. 311-373; idem, O różnych regułach dawnego prawa - 17 tytuł 50 ksieggi Digestów. Tekst - tłumaczenie - komentarz, Zeszyty Prawnicze [UKSW] 7.2, 2007, s. 297-345; A. Dębiński, [Komentarz] do ustawy julijskiej o sprzeniewierzeniu, świętokradcach i o zatrzymujących [pieniądze publiczne] - 13 tytuł 48 księgi Digestów. Tekst - tłumaczenie - komentarz, Zeszyty Prawnicze [UKSW] 8.1, 2008, s. 355-367; idem, [Komentarz] do ustawy julijskiej o bezprawnych zabiegach wyborczych - 14 tytuł 48 księgi Digestów. Tekst - tłumaczenie - komentarz, Zeszyty Prawnicze [UKSW] 8.2, 2008, s. 335-338; idem, [Komentarz] do ustawy julijskiej o porywaczach -15 tytuł 48 ksiegi Digestów. Tekst - tłumaczenie - komentarz, Zeszyty Prawnicze [UKSW] 8.2, 2008, s. 339-346. 
skiemu sprowadzałoby się chyba tylko do opowiadania fabuły filmu, którego nigdy się nie widziało (G. Negri, s. XIII). Trudno nie zgodzić się też z twierdzeniem G. Negri, że tym, co kształtuje umysł prawnika, jest przede wszystkim obcowanie z tekstami jurydycznymi, na nich bowiem oparta jest nauka prawa w Europie ${ }^{10}$.

Drobne uwagi krytyczne poczynione na kanwie pracy F. Scotii w żaden sposób jej nie deprecjonują. Należy pochwalić włoską romanistkę za trud, jaki włożyła w przekład tekstów i opatrzenie ich wnikliwym komentarzem, i oczekiwać, że zachęcona sukcesem swojej książki dalej ${ }^{11}$ będzie kontynuowała żmudną pracę tłumacza tekstów jurydycznych.

Piotr Kołodko

${ }^{10}[. .$.$] „Disponiamo bensì di libri che ci insegnano e ci aiutano a pensare, ma il valore formattivo della$ mente, che caratterizza il diritto romano, risiede sopratutto nei testi dei giuristi, nei casi concreti delle Pandette, sui quali è sempre stata costruita ogni rinascita degli studi giuridici in Europa" [...] - s. XIII.

${ }^{11} \mathrm{~W}$ trakcie druku jest także inna praca tej autorki: $l l$ testamento nel diritto romano. Testi con traduzione italiana e commento, l'editore ISU dell'Università Cattolica del Sacro Cuore di Milano, http:// docenti.unicatt.it/web/pubblicazioni.do z 24 sierpnia 2009 r. 